\title{
ASSOCIATION BETWEEN PLAYING GADGET AND THE RISK OF OVERWEIGHT IN CHILDREN UNDER FIVE
}

\author{
Santy Irene Putri \\ Faculty of Health Sciences, Universitas Tribhuwana Tunggadewi, Malang
}

\begin{abstract}
Background: A child is considered healthy if his weight does not exceed the appropriate growth curve of his age. World Health Organization states that obesity is a global epidemic that requires serious treatment. This study aimed to examine the association between playing gadget and the risk of overweight in children under five.

Subjects and Method: This was an analytic observational study with a cross-sectional design. The study was conducted at 8 Early Childhood Education Programs (PAUD) in Kediri, East Java. A sample of 127 children aged 2-5 years were selected by simple random sampling. The dependent variable was overweight. The independent variable was playing gadget. Confounding factors controlled for included age, gender, maternal education, paternal education, maternal employment, paternal employment, and number of family members. The data were collected by questionnaire and analyzed using multiple logistic regression tests.

Results: Playing gadget for $\geq 1$ hours increased the risk of overweight ( $\mathrm{OR}=23.59$; $95 \%$ $\mathrm{CI}=1.26$ to $442.04 ; \mathrm{p}=0.035)$. Age $2-3$ years $(\mathrm{OR}=2.93 ; 95 \% \mathrm{CI}=0.24$ to $35.37 ; \mathrm{p}=$ 0.398), mother's education lower than high school $(\mathrm{OR}=54.35 ; 95 \% \mathrm{CI}=2.48$ to 1191.10; $\mathrm{p}=0.011)$, father's education lower than high school $(\mathrm{OR}=70.98 ; 95 \% \mathrm{CI}=2.23$ to $2259.76 ; \mathrm{p}=0.016)$, mother as homemaker $(\mathrm{OR}=184.74 ; 95 \% \mathrm{CI}=1.43$ to $239.03 ; \mathrm{p}=$ 0.035), increased the risk of overweight. Paternal employeement, number of family members, and gender, did not affect the risk of overweight significantly.

Conclusion: Playing gadget for hours increases the risk of overweight. Age 2-3 years, low maternal education, low paternal education, and mother as homemaker, increase the risk of overweight.
\end{abstract}

Keywords: overweight, playing gadget, sociodemographic variable

Correspondence:

Santy Irene Putri. Universitas Tribhuwana Tunggadewi, Malang, East Java. Email: santyireneputri@yahoo.co.id. Mobile: +6285785836884.

The $6^{\text {th }}$ International Conference on Public Health

Best Western Premier Hotel, Solo, Indonesia, October 23-24, 2019 | 46

https://doi.org/10.26911/the6thicph.01.23 